\title{
Die Woord van God
}

Dit is my in hierdic kort skets te doen om slegs maar in paar grepe van die hele problematiek veral op Gereformeerde terrein. Die bedoeling is geensins on il uitpultende stuk te skryf oor alle moontlike aspekte in hicrdie verband nie. En dan wil ek dit baie graag benader vanuit die twee hoofpunte: I. GESTALTE. en 1I. SENTRIIM. met die beidoeling om van hieruil verdere vraagstukke aan te sny.

\section{GESTALTE}

\section{IIE WOORD AS (IESKREWE WOORD).}

..Nadat (jod baie keer en op baic naniere in dic ou tyd gespreek het tot die vaders deur die profele.." (Hebr. I:la). Gou het in dic ou tyd deur ..Moses en ciie Profelc" gespreek (Luk.24:4t. 16:31). Dit is wat ons vandag die (Ou lestament' noem en aanvaar. wat Jesus en Sy apostels ook as die .Skrifgeworde Woord van God' adanvaar het. Hiérop bedoel Paulus as hy verwys na die hele Skrif' wat deur God ingegee is (II Tim. 3:16) en Petrus as hy praat van die baic vaste profetiese woord (ll Petr. 1:19). Ofskoon Jesus baic gespreek het. het Hy - so het Luther geattencieer - Sy dissipels nooit opelrag gegee tot skrýwe nie maar wel tot prediking." Sy apostels het egter Sy woorde opgcteken asook baie van hulle .ere' prediking. wat ons vandag gesagvol aanvaar as die onfellbare Woord van Gol.:

In hierdie verband. veral ondat dit hier gaan om die aansluiting' van die Goddelike en menslike aspekte van cie Skrif, tree die cienaardigste gedagtes na vore. Marshall meen: ..Had anyone told the apostle (Paul) that his letters would one day be bound up with the Old Testament and the Gospels and be regarded as "Scripture". he would have been horrified at the idea and would have denounced it as blasphemous",3 John A. T. Robinson meen: . Maar dan bchandelt men de Bergrede als de nieuwe Wet. en ook al mag Matthèus Jezus zo hebben geinterpreteerd. er locpt vandag toch geen nieuw. testamenticus meer rond. die deze legalistische opvatting niet voor een foutieve verklaring zal houden".'()tio Weber is dan ook van mening dat .hier en daar (bv. 3:24) schijni Johannes ook de synoptici te willen corrigeren"."

Hierdie standpunte vinci in mindere of meerder mate sy neerslag in die Cieref. teologie. Tog sou dit onbillik wees on op die klank af te wil interpreteer. Nietemm $\mathrm{kom}$ daar gevaarlike elemente na vore as bv. 11. N. Ridderbos. met verwysing na l ukas. beweer dat .hij was niet zelf een oog- en oor-getuige geweest van Jezus. hij had hetgeen hij schreef ook niet langs een bizondere weg door de Heilige (ieest ingegeven gekregen. nee hij was, angestoken door hel voorbeeld of 
mischien ook uit onvoldaanheid over het werk van ..velen" voor hem .alles noukeurig ondersock". Hierdie voorbeeld moet dien on duidelik te maak, ,dat het enkele feit, dat iets in de Bijbel staat noch niet behoeft te beteken, dat het bijzoi!dere openbarings-betekenis heeft." ..Het goddelijke heft het menselijke niet op; het omvangt het en gebruikt het voor zijn doel. zonder het nochtans van het mensche. lijk.bepaalde en dus ook betrekkelijke te beroven" "i. Volgens dic vaste oortuiging van $\mathrm{Tj}$. Baarda .zal de opvatting die de betroubaarheid van de Schrift onlosmakelijk verbind met het historische gezag van de Schrift niet te handhaven zijn. wanneer men tenminste de Schrift echt au serieux wil blijven nemen": Israel se geskiedenis is nic op 'n band. opname vasgelê nie meen J. I.. Koole: ..Wie dat als eis van .Schriftgeloof ziet. doet daarmee onrecht aan de genuaceerdheid van de Schrift zelf".'

Dit kan vir geen oomblik ontveins word nie dat ons hier met ingrypende probleemstellinge te doen het, of beter: slit kan deur die mens ingrypend gemáák word." Dit kan nie ontken word nie dat daar (via Bultmann of Bartth?) 'n skerp verset na vore tlee tecu metafisiese tendense. Dit is 'n wins dat die oë deesdae weer oopgemaak word vir die ,menslike faktor", hoewel dit nie ontken kan word nie dat dit soms 'n sodanige beklemtoning ontvang dat ons weer verseild raak in 'n radikale horisontalisme en interiorisme. (j. C. Berk. ouwer kan nie genoegsaam beklemtoon in sy twee gedec studies oor ..De Heilige Schrift" dat ons in die Bybel noks te maak het met " ..buitewêreldlike" en ..botydelike" boek nie"': nie met "n verbluffes,d supranatureel ..mirakel"; die Skrif hom nie tot ons in ..abstracte supranaturaliteit"1z, die mensewoorde word nic ..vergoddelik" nie. ${ }^{1: 1}$

Dit is daarom opvallend dat H. M. Kuitert in sy studie ..De Realiteit van het Geloof" sku is vir die woordjie .openbaring". "t Ons moet dit by Kuitert waardeer dat hy op verruimende wyse alles weer in historiese verbande plaas. ${ }^{1 . j}$ Tog kan die vraag nie onderdruk word nie dat waar die eksistensialistiese teoloë die teologic probecr veilig stel deur in 'n transendente gebied te vlug. Kuitert dit probeer doen op ' $n$ horisontaliserende wyse as gevolg waarvan die transen. dente agter die horison dreig te verdwyn." kritiek op die eksistensieteoloë: .. Het .cschatologiseren' van de openbaring houdt bij de existentietheologie dirs strikt genomen niet in: demythologiseren van het christelijk geloof maar onthistoriseren daar. van. en dat zowel naar voren (tockomst) als naar achteren (ver. leden)" "1i. By alle verskilpunte met Kuitert is dit uiters waardevol dat hy nogtans aan die feite vashou as die harde kern van die evan. gelie." Inderdaad ... Het kerugma staat of valt met de feitelijkheid van het historisch gebeuren, walarvan het de proclamatic is".". .Als ci niets gebeurd was. zou er niet over te prediken zijn geweest en zouden er geen evangelieverhalen over in de bijbel staan" meen Schippers. "'a Dit is dan ook die waardevolle by Berkouwer dat hy, in dié verband t.o.v. (jen. I.3 vashou adn die .werklikheid".-" Dit skyn asof by Rome die gedagte algemeen ingang vind dat ons in die proloog van (ien. If 
doen hel mel simboliese verhale" en dat eers met Abram: vanaf (ien. 12 historiese figure" na vore tree."

Dic moderne teregwysing van hiblisisme' of bibliolatrie t.o.v. hulle wat hier enigsins .konserwatiewer' paaie hewandel. moet as 'n orvereenvoudiging van die hand gewys word. Dit is waar dat ons nie deur 'n blote formele aanmane" lan die Bybel as die Woord van Col die hele probleem opgelos het nie (juis teen hd. formalisme is Berkouwer se twee boeke gerig ..- waaroor later meer). maar dit is ook waar dat ons nic oor die formele kan heenstap of as formalisme kan afskryf nie. Sonder die (formele) besit en bestudering van die Woord kom ons inderdaad nog nie by die inhoud, die sentrum. die skopus uit nie. Slegs in de omosmaaklike samehang en innige vel. weefdheid van vorm en inhoud van die Skrif is daar in bevrydende oplossing gelec̈.

'n Waarskuwende woord leen formalisme mag nimmer inhou dat dic formele aspek' van dic Skrif gedevalueer word nie. Telkens sien ons hierdie aspek ook by die Here Jesus na vore kolil: .. Het julle nooit in die Skrifte gelees nie?" (Malt. 21:42): ..Julle dwaal ondat julle die Skrifte nie ken nie" (Mall. 22:29). Die Skrif moet inderdaad ook geglo word (Joh. 2:22). Paulus sê dat hy alle's geglo het wat in die wet en die profetiese geskrywe is (Hand. 24:14). Hoeveel maal gryp die apostels nie terug op die Skrifte nic. selfs op kleine letterlikhede soos in pratende slang (11 Kor. 11:3) en esel (11 Pert. 2:16)?

\section{DIF: WOORD AS VIEFS(IEWORDE WOORD}

het Hy in hierdie laaste dae tot ons gespreck deur die Seun" (Hebr. I:Ih). ..En die Woord het vlees geword en het onder ons gewoon ..." (Joh. 1:14a).

In hierdie verband spreek Berkouwer graag van die sentrum". die .skopus" van die Skrif. (Ons kon! later nog meer breedvoerig op hierdic punt terug (by II). Voorlopig kan ons noem dat dit opvallend is dat ook Totius 'n solanige .sentram' in Jic Skrif ontdek het. ..Dic Bybel is die Gexdsopenburing. Dil ontrou vir ons die Goddelike plan van verlossing soos gesentraliseer il' Jesus Christus. die Middelaar van (iol en die mense": 3

In die basisformule' van dic Cieref. Ekumeniese Sinode lees ons: ..It has to be emphazised that only a wholehearted and consisterit return to this Seriptural truth, of which the Coospel of Jesus Christ is the core and the apex. can bring salvation to mankind and affectuaie the so sorely needed renewal of the world"..".

Dit is verblydend om ook in hierdie verband op te merk dat kuitert realisties' bly. ..Hel gaat. ook in de christologie. on facts en niet on fansies".". . . onder de opstanding van Jesus (hristus is de heilsboodschap geen heilsboodschap meer; wij zullen dä met de apostel Paulus eens moeten zijn (l Kor. 15:lvv)." ".s

Veral dic apostel Paulus bring hd. sentrum skerp na vore in 1 Kor. 2:2: ..Want ek hel my voorgenecm on niks anders onder julle te weet nic as Jesus Christus, en Hom as Gekruisigde." In Ron. 
3:21-22 spreck hy ook van dic geregligheid van $(i x d$ wat geopenbad is. deur die geloof in Jesus (hristus. .terwyl die wet en die profele daarvan getuig". Die apostel Jchannes noen die Christologiese en Teologiese' skopus" in een asem: ...En dit is die cwige lewe. dat hulle $U$ ken, die enige waragtige Ciod. en Jesus (hristus wal I gestuur het" (17:3).

In hierdie verband het $S$. J. van dei Walt in betydse waarskuwende woord laat hoor deur die aandag te vestig op die tendens vandag. ..ook by die (jereformeerde cienkers. on die absolute gesag van die Skrif te devalueer. deur die Skrif as't ware uit te speel teen Christus wat . die lewende Woord is" 26

\section{DIE WOORD AS GEPREDIKTE WOORD}

..Gaan die hele wêreld in en verkondig die evangelie aan die ganse mensilom" (Mark. 16:15; vgl. Matt. 28:19. Hand. 1:8. Joh. 20:21). ..Daarom dank ons fiod ook sonder ophou dat. toe julle dlie woord vin (jod ontvang het wat deur ons verkondig is, julle dit aangeneen het nie as die woord van mense nie. maar soos dit waarlik is. as die woord van God wat ook werk in julle wat glo" (I Thess. 2:13).

In hierdie verband skyn dit soms of daar - selfs deur (ieref. teo. loë - 'n noodvlug gemaak word vanuit dic problematick van die .op Skrifgestelde Woord' na die gepredikte Woord'. (Ons wil graag 'n paar aanhalinge deurgee om op hierdie tendens te allendeer. Baarda sê dat 'n mens vir die (nie historlese?, nie wetinskaplike?') betroubaar. heid van die evangelies .geen sluitende argumentalie bieden. men kan haar alleen belijden en er van getuigen voor het forum der wereld" "? ..men kan over de betroubaarheid in deze zin alleen maar getuigen of preken ..."*-Schippers meen dat 'n evangolis ..han alleen maar vertellen als hij meteen predikt: en omgekeerd"... Overduin meen ook dal ..de verkondiging de hoogste vorm van watrheidsbetuiging (is)." (Ook Kuitert redeneer in hierdie trant as hy beweer dat ..het onder woorden brengen van de heilsboodschap in de taal van onze tijd gebeurt het best door deze praktiesc pogingen (prediking. pastoraat. sielsorg. onderlinge gesprek): in elk geval gebeurt het daar beter dan in de studeerkamer van de theoloog". "Geen wonder nie dat Van Ruler die billike vraag aan Kuitert vra: ..Is er alleen de predihing? Is er als moment in en als vorm van traditic niet ook de dognavorming. de belijdenis?" 3 :

C. A. van Peursen meen: ..Dogna's en theologie zijn gekort. wiekte liturgie. Pas binnen het gedicht. de psalm. de lofverheffing komen zij tot hun recht". . . .o zegt clke theologische pitspraak steeds te weinig. omdat hij de volheid der proclamatie inperkt. Als gekortwieke liturgie en schoorvoetende diakonie wijst de theologie. en elk. denken over ,Gal'. buiten zich. naar de diniensie van lofverheffing en dienst".34

Ook Berkouwer skyn in hierdie rigting te beweeg met sy bewering dat in die kultuursituasie van vandag. walar allerlei vrac rondom dic 
Bybel opdoem. ..is de prediking van het evangelie zeif de enige weg. waarop niet meer fluisterend. maar net dankbaarleid en in lof. zangen over de Heilige Schrift kan worden gesproken .." "3: Tig distansieer hy hon weer hiervan as hy in $n$ kriiiese voetnoot die beskouing van H. Diems afwys by wic daar in tendens aanwesig sou wees vir "n ..oplossing" ..v'ia die prediking". "3i Hy distansiezr hom ook van Bultmann en Kïhler. vir wis daar vir die geloof geen ander legitimasie is nie. geen ander betroubaarheid as die van die rerkendiging. Ook hiér cink Berkouwer sterk .sentraliserend". Hy noem dat die problematiek eers dan ipkon ... Wanneer men de graphe wit z'n verbanden abstraheert en ..op zigzelf " gaat benaderen -- als letter :- en dan het levende woord stelt tegenover het verstarde. gestolde woord"..34. .Wanneer deze centraliteit en gerichtheid van de prediking der graphe vervagen, wordt alle prediking onceloofwaardig naar alle zijden. wordt alle rhetorica en nadrukligkheid en accomoda. lie ridicuul als vorm zonder inhcud. zonder betrokkenheid op de (ieest die Christus verheerlijkt

Berkouwer beklemtoon dat vir l.uther ..deze boodschap als declaratie. als kerugna van het heil het besiissend aspect van l.uthers bemoeienis met de claritas (is)" "." maar hy waarsku teen "n voorbarige konklusie as sou hierdie aksent op die prioriteit of ..primaat" van die gesproke woord, ooit by l.uther die aandag vir die geskrewe woord sou uitsluil." Berkouwer verwys in hierdie verband graag na Calvyn." vir wie mens onwelwillend van subjektivisme sou kon beskuldig as Calvyn beweer dat, zolang uw hart niel zichzelf over die zekerheid in strijd zal zijn. zal ook het Weord van een twijfelagtig en zwak. of liever van generlei gezag zijn"." Die skrif het gesag by die gelowiges. sê Calvyn, as hulle glo ..dal ze uit de hemel is voontgekomen. evenalsof levende stemme cickls zelf var. daar gehoord werden." ". En onwillekeurig dink mens aan die woorde van Hebr. 4:2: "Want aan ons is die evangelie verkondig net soos aan hulle; maar die woord van die prediking het hulle nie gehaut nie. omdat dit by die hoorders nie met die geloof verenig was nie." Niemand sal wil heweer dat hiermee die Woord van God afhànklik gemaak word van die geloof van die mens nie. en dat die Woord eers dan Woord word wanneer dit gelowign. aangeneem word nie. maar hier word indeidaad op diepsinnige wyse die korrelasie Woord-geloof geopenbatar. Sonder die geloof. báát die Woord nie."

In die prediking gaan dit on feite wat verkondig moet word met die doel om tol die geloof te bring (Joh. 2():31). Die evangeliste het geskryf met "n spesiale duel: .het oprocpen tot geloof"." Dit gaan egter on die verkondiging van werklike gebeurtenisse. Ons mag nie vlug. sê Berkouwer. ,in een dissociatic van duidelijkheid en feitlijkheid. van kerugma en geschiedens. In de duiding is de blik geen ogenblik afgewend van wat geschied is . . " Dit was l ukas te doen on ... wat werklijk geschiedde en niet on los van de geschiedenis staande ware ideeen. Wat hy gaat verhalen is niet een esoterisch geheim. maar een door ooggetuigen meegemaakt en nu verhaald en doorgegeven gebeuren"." Dit is duidelik dat .het getuigenis der prediking zou dan 
een ruls getuigenis zijn, onsdal or geen werklijhlheid achter statat. Scherp keert het ganse N.T. zich tegen de gedachte. dat de boodschap des heils een eigen creatic of projectic zou zijn. een verdichtsel van de menselijke geest"." Dit is alles waardevolle momerite in due teologic van Berkouwer. H. Berkhof maak egter dic kritiese opmerking dat. ondat Berkouwer nou in sy derde fase' is, die fase van ..de existentiële strekking van de Schrifi". ..de feitlijhheial uitsluitend onder haar gezichsipunt van haa existentaliteil beiaderen. M.i. zit daar het dubieuze punt. Imners: krachtens de correlatie zijn wij het die de wegen en grenzen der existentialitcit bepalen".."

Oor die ,werklike gebeure' en die verkondiging van hierdic sebeure is daar vandag veel roerıng. Mens dink in hierdie verband aan die Bultmanniaanse hermeneutiek en eksegese. Ook daaraan dat Berkouwer genuanseerd onderskei tussen sî̀ mar 'n gewone' ontnitologisering en 'n ,radikale' ontmitologiserin⿺ soos b) Bultmann c.s." Kuitert praat ook van 'n ontmitologisering van die hele (icref. wêreld.": $j a$, dat selfs die Reformatore (l.tither en (alyyn) al begin het met in .ontmitologisering' van die teologie. 'n deurbreking van die netafisiese teologie:3 - vgl. die hellevaart en Nagmaal. Küng wil ook graag van ontmitologisering gebruik maak ...als daarmee bedosk! wordi dai ook Jezus' boodschap over de godsheerschappij !it de situatie en hel mythologische wereldbeek van die tijd vertald moer worden in onze huidige situatie en het molerne wereldbeeld ..."it

Arntzen vra 'n kritiese vraag aan Baarda: ..Cclooft Baarda wel. dat we hier met een geschiedenis te doen hebben?. En als men zo witermate critisch gaat staan tegenover de geschicdenissen, die de Heilige Schrift ons mededeeit. heeft men dan een waarborg. dat de heilsfeiten dan ook niet door de critiek worden aangetast?" "Wa Wat verstaan Arntzen onder geschicienissen" en onder heilsfeite en is hierdie onderskeiding Skriftuurlık verantwoord? Ons staan hier vocir die probleem van dic konsekwensies'. Berkouwer bring dit ter sprake as hy vra of ons by in ..metexacte beschrijving nog wal van iets" zeker kunnen zijn en of op leze wey nici ..per conseyuentam" alles ons ontvalt". Hy ag dit noodsaaklik dat ons beurıp most hê vir hierdie vrees." Hy ag dit nodig lat ons nie ons oë moet sluit vir die vele gevare van die ..konsekwensies" nıe. en hy meen dat die stryd om .deze consequenties of implicaties de achtermrond vormt van alle confessionele verdeeldheid.". Is dit egter billik en wetenskaplik om konsekwensies uit iemand se staindpunt te trek as hy self daardie konsekwensies uitdruklik van die hand wys'?

\section{DIE WOORD AS BIIITE.BYBEI.SE WOORD?}

In hierdie verband dink ons nie in ecrste instarsie aan dis Roomse tradisie nie. Berkouwer veiwys na die Tweede Vatikaanse Konsilie waarvolgens die tradisie mé 'n aumbullende karakter besil. náás die Skrif nie. Küng en Rahner is ook hierdie mening toegedaan." S. J. van der Walt kom tot 'n ander konklusie."

Dit gaan hier veral oor die standpunt van (i. Th. Rothuizen. Volgens sy mening kom ons bv. die etiese ook ,buiten het christelijke 
tegen ... Troost heeft gelijk. wannecr hij zegt. dat bv. een huwelijks. ethick .nooit uitsluitend aan de Heilige Schrift kan worden ont. leend" . . . Het betekend ook ... dat men zich niet ontzag on in er.ı boek as de Spreuken wijsheder van huiten Israël, algemene regels van goed en kwaad, ordenitg des levens. zede. ethiek dus. te halen" ".1 ..Wanneer dezelfde Paulus het jonge christendom van een ethiek moet voorzien. grijpt hij. behalve naar de wereld van het O.T.. eenvoudig naar die van zijn dagen. pakt hij naar wat o.d. Stoa hem te bieden had" it" Christelike etiek is demitologiserend ..zij leert ons immer te breken met de mythe van hel monopolie van het dogmatische. theologische en zelfs christelijke in je ethick. Zij durft m.a.w. te ontdogmatiseren. ontheologiseren en zelfs ontkerstenen. Daarna maar ook al daarin en daarmee -- mag ze kerstenen, theologiseren en dogmatiseren naar hartelust".;3 In Geref. Weekblad word genoem dat ..de bijbel deelt haar normen veor een niet gering godeelte met ..de omgeving": de bijbel staat niet alleen maar in de bijbel. In zoverre hadden de etischen althans half geclijk. toen ze zciden. dat iets goed is. niet ondat het in de bijbel staat. madr dat het in de bijbel staat omdat het goed is - als ze dat tenminstte ooit gezegd hebben". En dan volg weer die verwysing na Spreuke. .dat nu niet bepaald de toppunt van evangelisch verkondiging mag heten en waarvan de regels ook ver buiten de bijbel voorkomen . . " "6it Die probleempunt is hier nie dat daar inderdaad ook waarheidselemente buite die Bybel in die heidendom te vind is nie - wadrom sou dit nie reste kon wees van Giod se oorspronklike openbaring nie?. - maiar dit gaan hier oor wàt in die Bybel staan. en oor die genoégsaamheid daarvan, asook oor wáárom dit in die Bybel staan. Het ons nie hier by Rothuizen 'n devaluering van die genoégsaamheid van die Skrif nie. 'n formalisering daarvan. ondat dit nie afgestem is op die skopus' nie? - vgl. die ,nie-evangeliese" Spreuke, dic ,ontkerstenen'.

Hoe vloeibaar die grens tussen .besondere' en algemene open. baring' deesdae geag word. blyk duidelik uit die voldoende bewering van C. A. van Peursen: .. Dıt alles wil niet zeggen. dat de Israëliten over meer en heel andere. bovennaluurlike. informatic aangaande (jol beschikten dan de mens van vandaag". ;is . .Telkens, moet het onde $e$. kennen van de Naam opnieuw begirinen. ook vandag als men de gang van het hedendaagse gebeuren echt recht wil doen en bevrijuencis perspectieven ontwaren in het wereldbeek en de machten van de molerne tijd". "is (Ons is hier gedeeltelik op die glibberige en moeilike weg van die .duiding van die geskiedenis."

\section{SENTRUM}

Waarop rus die herk? Het die Skrif so in basisformule'. i: shopus': 'n sentrum"? Ons het reeds by 1. 2 verwys na enkele uitsprake in hierdic rigting. maar wil hier graag breedvoeriger daarop ingaan.

Die hart van die N. Te getuienis waarop die kerk rus is inderdaad die belydenis van die rols-apostel Petrus: .U (Jesus) is dic 
Christus, die Seun van die Icwende God" (Matt. 10:16). Soos "n refrein kon hierdie belydenis in die N.T. telkens terug. soms wel swak en vaag omlynd. Dit kom voor by Natanael (Joh. 1:50)), by Martha (Joh. 11:27), by die hoofman oor londerd (Matt. 27:54). by Thomas (Joh. 20:28). Na alle waarskynlikheid was die eerste belydenis van die vroee kerk net: ..Jesus is dic Here" (1 Kor. 12:3: Filipp. 2:11). Al wat 'n mens moet doen on yered te word. is slegs on in die Here Jesus te glo (Hand. 16:31), en ook dat (iod Hom uit die dode opgewek het (Rom 10:9). Vir die Joud is die groot struikelblok gelec in verbinding van Jesus enersyds. met Messias on Seun van Gol andersyds (Luk. 22:7()-71). Vir die heiden is dit 'n dwaasheid dat die Gekruisigde ook die Opgestane kan wees (Hand. 17:32).

So eksklusief is hierdie weg dat Jesus kon sê: ..Niemand hom na die Vader behalwe deur My nie" (Jch. 14:()). Petrus nuem dat daar geen ander naam' is waardeur ons gered moet word nie (Hand. f:12). So uniek is hierdie weg dat Jesus vir die Jole kon sê dat hulle (iixd nie ken nie ondat hulle Hòm (Jesus) nie ken nie (Joh. 7:28, 8:19, $55)$.

In die aangesig van Jesus sien ons (jol Self (Joh. 1f:9). In Hom het al die volheid van (iod liggaamlik gewoon (Kol. 2:9). Hy is die beeld van die onsienlike (jod IKol. I: 15), ja. (jod is openbaar in die vlees (1 Tim. 3:16).

Daarom sou ons, reg besien, nic beswaar kon he teen die gedagte van 'n .sentrum' in die Skrif nie, maar nié as sou die periferıe van minder betekenis wees nie. Met hierdie gedagte word alle formalistiese Skrifbeskouinge gesloop. omdat ons in dic Skrif onmiddellik te doen het met die boodskap van die Skrıf Dit kan nl. nie ontken word nie dat 'n blote formalistiese ongang met die Skrif inderdaal baie móntlik is. Die owerpriesters en s.krifgeleerdes kon ilykbaar met teks en kapittel die geboorleplek van de Messias adnúui (Miga 5:1), terwyl hulle sèlf nie gegáán het nic .Matt. 2:6). Jesus sê vir die Jode dat hulle Moses nie glo nie omdat hulle Hom nie glo nie. .maar as julle Moses geglo het. sou julle My glo. want hy het ran My geskrywe" (Joh. 5:46). As die ryk man se vyf broers .Moses en die Profete' besit het. dan het hy dit ook na alie waarskynlikheid besit. maar tog die ewige lewe gemis onidat $h$, nie na die Woord wou! luíster nie (Luk. 16:31). Jesus moes dis geslote oe van die Emmaus. gangers open „van Moses en al dic Profetc af en vir hulle uitgele in al die Skrifte die dinge wat op $/ 1 \mathrm{om}$ betickking het" (I.uk. 24:27). Nadat Johannes sy' lang evangelie geskryf het. val hy die dciel daarvan in een sinnetjie saam: ,maar hierdie is beskrywe. dat julle kan glo dat Jesus die Christus is, die Seun van Ciod: en dat julle deur te glo die lewe kan hê in Sy Naam" (Joh. 20:31). I illippus moes vir die kamerling. wat die Skrif geléés matar ne verstáan het ne. vanuit Jesaja ,die evangelic van Jesus aan hom verkondig" (thand. 8:35). Koning Agrippa het die profete geglo' mar tog nie "n ('hristen geword nie (Hand. 26:27-28).

Daarom is S. C. W. Duvenhage se poging watardevol om nic ..op skolastiese wyse mel in formele opvalling, afgesien van die in. 
houd van die Skrif. voor "n dag te kom ric". Tereg beklemtoon hy dat ..die Skrif nooit van sy boodskap losgemaak mag word nie. Die gesag van die Woord văn God kan alleen verstaan word vanuit die aanvaarding van die inhoud van die Woord self as swaard van die (jees". "Hy meen ook dat die openbaring van God sy ..hart vind in die vleesgeworde Woord. Jesus Christus" en dat dic suiwere visic op die Skrif alleen moontlik is ..vanuit die betrokkenheid van die heilswoord op die heilsgeskiedenis"."i" Lekkerkerker sê hierdie vir kritick valbare -- woord i.v.m. dic Heidelbergse Kategismus: ..De Heidelberger is méér geinteresseerd bij het levende sprekien Gods tor profeten en apostelen bovenal in zijn Zoon Jezus Christus. dan bij de schriftelijke teboekstellıng. Hij is meer Christusgelovig dan bijbelgelovig. Mede daardoor zegt hij niets over het gczag van de over. levering. een $k$ westic dic echt belangrijk wordt wanneer men een leer van de Heilige Schrift gaat geven"." Dit is "n valse dilemma om die .Skrifgeloof' teen die .Christusgeloof' uit te speel - asof ons die Skrif kan glo. los van Christus om. en asof Christus nie tot ons kom deúr die Skrif nie.

.. In die diepste $\sin$ van dic woord. is alleen Christus volgens die Bybelse verkondiging onmisbaar vir dic kerk"." maar tog moet ook gesê word ..dat die kerk sonder die Skrif nie kan leef en bestaun as kerk van (jod nie"."?

$\mathrm{Al}$ is dit moeilik naspeurbaar. wil Polman log spreek van in sentrale boodskap' in die prediking van Augustimus. ..Daaron ver. klaart hij (Augustinus) ook openlijk en ronduit, dat alleen een prediking. die Christus brengt. tot het doel leidt . . "

Bekend is ook in die verband die standpunt van l.uther. Kanonick is vir hom alleen daardie boekie ..was Christum treibt". Dit had ten gevolg dat hierdie reformator tot kritiese uitsprake t.o.s. sekere Bybelboeke kon kom (vgl. sy oordeal oor die .brief van Jakobus'). Die kritiese vraag is aan die Reformasie gestel of ons nie ..midden in het reformatorisch cenken - met zijn nadrukkelijk ..sola Scriptura" - een kritich aantreffen, die zich boveil de Schrift stelt en haar gezag en normativiteit voor en in de kerk aan een kritische beoordeling onderwerpt" " Berkouwer meen dat ons by l.uther wel kan spreek van "n ..Christologisch canonbegrip" of van "n ..heilshistorische canonicitcil" " mar hy wys die gedagte af as sou l.uther voor "n subjektivisme gekapituleer het; .het zou ongerechtvaardigd zijn l.uthers Schriftbeschouwng vrijwel uitsluitend te benaderen vanuit deze incidentele problenratiek. die tenslotte toch mier leidde tot de destructie van het in de canon betuigde evangelie" ".." (Vgl. die .konsekwensie'-gedagte)

(Ons wil hier nader ingaan op dic standpunt van Berkomier self. Dit sou nic oordrewe uees nie om te stel dat hy albei sy dele ocr die Heilige Skrif geskryf het in skerp konfrontasie met die formalistiese Skrifbeskouing. Ir beide dele kom die skopus herhaaldalik terug. hadas by elke hoofstuk weer. Beide dele word beheers deur die .litgangspunt van B. se teologie: dic korrelasic openharing/geloof. Ook hier gaan dit vir hom vir geen enkele oomblik om die formele 
lòs van die inhoudelike on me. Inderdaad gáán dit ook oor die fór. mele. maar dan onlosmaaklik verbind met dic sentrum'.

Sprekende oor die formele. abstrakte Skrifbeskouing. noem Berkouwer dat die Skrif hier gesien word .als geschrift, als boek van Goddelijke qualiteit, zonder dat daarbij van het begin af de inhourl. de boodschap van de Schrift word méégedacht. We raken hier ven ingrijpend punt der Schriftleer ... it Hy toon aan hoedat Bavinck aan alle formaliteit en isolering en alle dualisme tussen Skrifgeloof en Christusgeloof ontkom het." ..Belangrijk is zowel bij Bavinck als bij Kuyper de duidelijke afwijzing van de gedachte. als zou de Schrift. afgezien van haar boodschap het voorwerp van testimonium zijn"." Berkouwer het ..geen enkel bezwaar om van ...Schriftgeloof" te spreken, want die Emmaiisgangers en ons word gewaırsku ...egen elke devaluering van het geschreven en gepredikte Woord"." In dic geskrewe en gepredikte Woord gaan dit telkens onlosmaaklik on dić Woord, Jesus Christus. Daarom kon die walarskuwing dat 'I tradisio. nele Skrifgeloof nie kan bly bestaan nic ..wanneer de levende band aan de boodschap der Schrift niet meer het leven tot in het hart beheerste"..1 .Uit het onbevredigende van allerlei soluties van het canonprobleem zoals in de verwijzing naar de providentia Dei, de getuigenis des Geestes en de autoriteil der kerk blijht voortdurend. dat er geen enkele geisoleerd instantie is, die butten de inhoud cn dieptc van de canon zèlf om, een verklarend licht kan werpen op de vorming en de gelding van de canon. Maar bovenal kan men zich niet onttrek. ken aan de indruk, dat in deze oplossingen de canon zèlf wordt gedevalueerd. De relatie tussen canon en geloof wordt hier nl. steeds belicht vanuit een min of meer theoretische verklaring. waarin men meent het gezag van de canon te kunnen verduidelijken". " Oor hierdie gelade woorde sal daar, veral in die lig van art. 5 N.(i.B. nog veel geteologiseer moet word. I eenoor Rome (Rahner). wat die kanonprobleem ekklesiologies tot oplessing bring, handhaaf Berkouwer dat die .zekerheid alleen te verstaan (is) vanuit de boodschap des heils ..." terwyl hy terloops daarep wys dat ons nie in die kanon tussen sentrum en perifeiie noet onderskei ,alsof perıferic onbelangrijk zou zijn". 3 Volgens hom is ..een waruchlige belijicris van de Heilige Schrift alleen mogelijk door zich aan het getuigenis der Schrift gewonnen te geven. Alleen op deze weg van het geloof grocil de zekerheid aangaande de Schriften als hei gewade, waarin Christus tot ons komt naar Calvijns diepe en zinvolle formulering"." Wic die eenheid van die H.S. en die boodskap van die Skrif verbreck ..en het ene ware geloof opsplitst, tast niet alleen de zekerheid des geloofs aan, maar doet dat door de $z i n$ van het Schriftgeloof op te heffen en te seculariseren".si

In Deel II kom hierdic gedagtes herhaaldelik terug. ()ok l.a.v. die teopneustie van dic $H$. S handliaaf hy dat dil nic meer formes verstaan kan word nie, ..ook met vanuit cen algemene instrumentaliteit. maar moet gezien worden in verband mei de werklijkheid des heils, warvan de Schrift gentuigt".". Hel geheim dei theopneustio" bedoelt ons niet te stellen voor ten theoretische problematick. hoc 
het mogelijk en denkbalar is. dall de Schrift Gods Woord en mensenwoord is en hoe ze "verenigd" kunnen worden. madar stelt ons vour het geheimenis van Christus" "a. Wanneer die Skrif ..ran Christus getuigt en dus 1 an $/ / e m$ als het Wonrd ciols onjerscheiden is. dan is dat geen relativering van de Schrift. maar de erkenning van haar zin, gerichtheid en funclie". " Die geloof van die Skrif . is niel het aanstaren van een heilig en mystericus boek. malar het horen van het getuigenis aungande ("hristus"." Aldus kalı bickouwer tot hierdie gewigtige konklusie kon: ..Daratsor wordt het zinvol en noodzaaklijk te bedenken. dal we in de Schrift niet in aanraking komen met cen openbaring van een (jodjelijke waarheid (of waarhede) waarover wij zouden kunnen spreken buiten het getuigenis. karakter dezer verba om"." Hy ontken nie dat daar "waarhede" in die H. S. is nic. maar wel dat melis oor die waarhede geisoleerd kan spreek buite dié Waarheid om (Joh. 14:6, 5:46). Hoe het dit gekom dat Jood en Christen die O.I. radikaal verskiliend inteıpreteer? Nié in die tegniek of metodes van Skrifgebruik nie. mar in die ,.totale en centrale inzicht in het ().l. als getuigenis van de belofte van de (jod van Israel en in de realiteit van lezus als Messias"." In hierdie verband doen die woorde van Koole onweldadig aan nl. ..dat men de N.T. ische exegese van het O.T. wei hoog kan daislaan, doch haar toch allerminst geheel normatied kan achion voor onze hedendaagse exegese"." Ook aangaande die hetroubaarheid" van dic H.S. gekd vir Berkouwer dat .ze is geen theoric, die aan het vertrouwen vooraf. gaat en dit vertrouwen mogelijk maakt en zo komt tot een tweevoudige zekerheid aangaande de $\boldsymbol{S}$ chrift in aangaande haar borkt. schap": Dieselfde skopusgedagte kum by die duidelikheid van die Skrif ter sprake. .Over de perspicuitas werd niet gesproken, los van het perspicere, het zien en het doorzien, net verstadn van de boodschap der Schrift"."3 H. W. Rossouw kom tot dieselfde konklusie." Die gehoorsame .onderwerping" aan die Schrif is "n geloof wat alle blindheid mis en dit rus nie ...n een ovcrtuiging aangaande een formele autoriteit. die geloofd moet en kan worden, afgezien van wat zij heeft gesproken"." Diar is altyd die groot moontlike on. moontlikheid oop. ..men kan ..Bthlehen" ontdekken in de Schriften zonder de weg naar Bethlehem te gaan en de Schriften onderzoeken zonder tot Christus te komen. de Schrifte! lezen en toch dwalen en de Schriften niet kennen. Fr is een toeganklikheid der woorden. maar deze garandeert nog niet de kennis van het geheim." "wi

By alle kritiekpunte teen Berkouwer. is dic wdardevolle van sy Skrifbeskouing sekerlik gelee in die siopus-gedagte. waardeur hy mot alle formalisnie afreken. ()ns sou kon se. dis die bevrydende in hierdie studies.

I. I1. van Wyk.

VERWISING iS

1. By (i. C. Berkouwer. ..l) Heihge Schrifi" II. Kok-kimpin. 1967. vertnow so. $p .394$

2. Vgl. hicrvour o.a. S. ( . W Duvenhage. .Dic (icsag van dic lleilige Skrif". Polchefstroom, 1967, pp 27-29 
3. 1. II. Marshall, .. Ihe (hallenge of New Iestament Ethics". London. 1960. p. 218.

4. John A. T. Rohinson, ..Eerlijk voor God"., Amsterdam. 1964, p. 117.

5. Otto Weber, .De Boodschap van de Bijhel”. Wageningen. 1958. p. 103.

6. In ..Ceref. Weckblad" 19 Maart 196.5. p. 266

7. In ..Geref. Theologisch Tijdschrift". Mei 1966. p. 102.

8. J. L. Koole. .Verhaal en Feil in het Oude Testament”. Kok-Kampen. s.j., p. 49.

9. Vgl. Duvenage. a.w. pp. 18-19.

10. (j. C. Berkouwer, ..De Heilige Schrifi I. Kok-Kampen. 1966, p. 91.

II. A.w. II. p. 14.

12. A.w. II. p. 105 .

13. A.W. II. p. 114: vgl. ook p. 139 Sien ook II. N. Ridderbos, ..Het Woord. het Rijk. en onze verlegenheid". Kok-Kamnen. 1968. pp. 57-77.

14. H. M. Kuitert. „De Realiteit van het Geloof”. Kok-Kampem. 1966, veral p. 182.

15. Idem. pp.168. 207.

16. $V_{g}$ l. idem, pp. 147, 16.5 .

17. Idem, p. 123.

18. Idem, pp. 176. 180, 181, 184. 197.

19. H. N. Ridderbos, .Heilsgeschiedenis en Heilige Schrift". Kok-Kampen. 1955. p. 111.

19a. In ..Cieref. Theologisch Tijdschrift". Febr. 1968. p. 52.

2). A.W. II. p. 319: vgl 316

21. .De Nieuwe Katechismus". Hilversum-Antwerpen. 1966. p. 307: vgl Hans Küng. .De Kerk". Hilverstm-Antwerpen, 1967. p. 75i. il. 11 . Kuitert beweer ook dat die televisie ons kom leer het .dat (jen. 1-3 niet letterlijk kloppen" (Geref. Theologisch Tijdschrift. November 1966. p. 211). Hy skat dat ... ie natuurwetenschappen studeert. leest de bijbel... minder naïef. minder vanzelfsprekend. . " (1dem. p. 213). .(Over (ienesis 1.. . denken velen anders dan het gereformeerde voorgeslachi" (idem. p. 214). In in kategetiese handboek (G. P. Harticlt en $H$. M. Kuitert. ..In de Kring". Delfi. 1965) word gesé dal die veelheid van (skeppings-) verhale duidelik maak dat ..de bijbelschrijvers in beclden. ontleend aan hun eigen tijd. Gods scheppmgswerk verkondigen" (p. 41: vgl. ook pp. 40 en 42).

22. J. D. du Toit, "Die Bybel is die Woord van Gind". Stellenbosch. 1941. p. 42.

23. RES. Agenda Reports. Michigan. 1968 p. 215.

24. In ..Kerk en Theologie". Juli, 1965. p. 198.

25. Idem. p. 203. So ook in ..(ieref. Theologisch Tijdschrifi". Febr. 1968. p. 94.

26. In ..Kuers". Jan. Febr. 1966. p. 263.

27. $\mathrm{Tj}$. Baarda. ..De Betrouubaarheid van de Evangelien" Kok-Kampen. 1967. p. 87.

28. Idem. p. 90 .

29. In Geref. Theologisch Tijdschrift". Aug. 1968. p. 198.

30. In ..Verkondig het Woord" I. Wever-Franeker. 1958. p. 206.

31. Kuitert. .. Realiteit". a.w. p. 128.

32. In ,Kerk en Theologie", Juli 1967. p. 208. Vgl. Kuitert se hritick op Pannenberg: „Wij komen bij de omkering van Bultman terecht. Niet de prediking (het Woord) slokt de gebeurterissen op. mar de gebeuitenissen de prediking" (... (jeref. Theologisch Tijdschrifi". Febr. 1968. p. 92).

33. C. A. van Peursen. ...Hij is het weer Kok-Kampen. s.j.. p. 63 .

34. Idem. p. 64.

35. A.w. I. p. 76 .

36. Idem I. p. 222. voutnoot 380 .

37. A.w. 11. p. 205

38. Idem 1I, p. 396

39. Idem II. p. 405

40) Idem II, p 270. 
41. Idem II. pp. 394-395

42. A.U. 1. p. 180: II. p. 375

43. J. Calvyn. .Institusie". Meinema- Delit. III. 2. 6

44. Idem. I. 7. I.

45. Vgl. Berkouwer. a.w. I. p. I36.

46. Berkouwer. a.w. II. p. 210

47. Idem II. p. 219

48. Idem II. p. 220.

49. Idem II, p. 225.

50. In ..Ex Auditu Verbi". Kok-Kampen. 1965. p 53.

51. A.w. II. p. 239 e.v.

52. In ..Cicref. Theologisch Tijdschaift". Nov, 1966. p. 211

53. Kuitert. ..Realiteit". a.w. pp. 154. 158

54. Küng. a.w. p. 75 .

55. In ..(jeref. Theologisch Tijdschrift". Aug. 1966. p. 157

56. A.w. II, p. 212.

57. Idem II. p. 281.

58. Vgl. .. Geref. Teologisch Tijdschrifi”. Febr. 1965. pp. 13-14: ..Geref. Wickblad". I Okt. 1965.

59. A.w. II. p. 343.

60. In ... In die Skriflig". Apr.-Mer 1968. p 32.

61. In ..Cieref. Theologisch Tijdschrifi". Nov. 1967, p. 277.

62. Idem, p. 278

6.3. Idem. p. 279 .

64 ..Cieref, Weckblad". 8 Dec. 1967. p. 159

65. Van Peursen. a w.. p. 18.

66. Idem. p. 19.

67. Vgl. Murray Jansön. ..Dic Kerk en die Ideologie". Potchefstroom. s.j.. pp. $47-51$.

68. Duvenhage, a.w. p. 8.

69. Idem. p. 9.

70. A. F. N Lekkerkerker. . Gesprekken over de Heidelberger". Wageningen. 1964. D. 79.

71. J. H. Roberts. ..Kerk en Skrit”. Potchefstroom, s.j., p. 29.

72. Idem. $\mathrm{P} 26$.

73. A. D. R Polman. ..Hel Woord cods bij Augusinus". Kok-Kampen. 1955. p. 146 .

74. Berkouwer. a.w. l. p. 121 .

75. Idem I. p. 122.

76. Idem I. p. 124

77. Idem I. p. 45.

78. A.w. I. p. 47 : II. p. 67

79. A.w. I. p. 48 .

80. A.W. I. p. 67: II. p. 245

81. A.w. I. p. 76.

82. A.W. I. p. $I(x)$

83. A.w. I. p. 111.

84. A.W. I. p 136

8.5. A.w. I. p. 136.

86. A.w. II. p. 51

86a. A.w. II, p. 52

87. A.W. II. p. 55

88. A.W. II, pn 55.56

89. A.W. II. p. 56

90. A.w. II, p. 177

91. By Berkouwer, a.w. II, p. 167

92. A.W. II. p. 206.

93. A.W. II. n 260: vgl. p. 329.

94. H. W Rossouw, "Klaarheid en Interpretasic". Amsterdam, 1963, stelliatg I. Vgl, $R$ Bijlsma. ...Schrifigezag en Schriftuchruik" 1964

95. Berkouner, a.w. II. p 424

96. Idem II. pp. $443-444$. 